Journal of Critical Race Inquiry

Volume 7, Number 2 (2020) pp. i-xx

\title{
Introduction to Special Issue: Whiteness in the Age of White Rage
}

\author{
Katerina Deliovsky \\ Department of Sociology, Brock University \\ Tamari Kitossa \\ Department of Sociology, Brock University
}

\begin{abstract}
This Special Issue — "Whiteness in the Age of White Rage" — names and interrogates what is implicit in anti-racist, Indigenous, and whiteness studies: white rage. Drawing on Carol Anderson's White Rage: The Unspoken Truth of Our Racial Divide (2017), we invited scholars to explore empirical and theoretical inquiry of how rage is a defining characteristic of settler colonialism, whiteness, and white supremacy in Canada. In this Introduction we elaborate how contemporaneously, historically, and theoretically a vital dimension of the configuration of whiteness in Canada is the normalization of rage as a property right of whiteness. Presently, as fascism is once again a global phenomenon, there is an opportunity for critical scholarship on whiteness in Canada to name and explicate the social effects and quotidian mobilization of rage in conservative and liberal articulations of white supremacy. We offer a general outline to the theme of whiteness in the age of white rage to introduce nascent scholarship that builds on the scholarship of Black, Indigenous, people of colour, and critical whiteness scholars.
\end{abstract}

Keywords: anger, colonialism, middle class, racial capitalism, settler-colonial state, white rage 
People who shut their eyes to reality simply invite their own destruction, and anyone who insists on remaining in a state of innocence long after that innocence is dead turns himself into a monster. (Baldwin, 1955/1984, p. 175)

The true credo of the white race is we have everything, and if you try to take any of it from us we will kill you. This is the essential meaning of whiteness. (Hedges, 2017)

White anger - deep, seething, and quotidian — is a fact-of-life in Canada. Its expression, channelization, production, and collective legitimation was manifest from the first moments of settlement and, through praxis, normalized in the culture over time. Because it does not conform to the dominant multiculturalist and post-racial narrative propagated by the state and much of (white) civil society, this idea may be opposed as hyperbole. We suggest denial of the existence and ubiquity of white rage is itself an assertion of power motivated by anger that occludes the continuities of colonialism, racism, and slavery in Canada.

Indigenous, Black, and racialized scholars in Canada explicate both resistance to and the tremendous costs of the historical and contemporary configurations of capital, race, and whiteness in the making of the nation-state. A select survey of the scholarly literature attests that the economic, cultural, and political foundation of the nation-state pivots around the centre of whiteness. Indigenous scholars point to colonialism as a totalizing regime of domination and genocide against which fierce and ongoing resistance has been mounted (Anderson, 2016; Coulthard, 2014; Lawrence, 2002; Tuck \& Yang, 2012). Black Canadian scholars point to the corrosiveness of slavery and Jim Crow and their afterlives in shaping pervasive anti-Blackness (Austin, 2013; Foster, 2019; Henry 2015; Lawson, 2002; Nelson, 2018; Walcott 2003; Walker, 2010; Whitfield, 2019). Other scholars of colour point to the role of whiteness in the moral, political, economic, and spatial management of neoliberal subjectivity (Bannerji, 2000; James 2020; Ng, 1993; Razack, 2002; Thobani, 2007). White Canadian scholars have also documented the historical and contemporary covert/overt articulations of whiteness in Canada's social, institutional, and legal order (Allen, 2020; Backhouse, 1999; Coleman, 2006; Deliovsky, 2010; Levine-Rasky, 2013).

Yet, in spite of works that alert us to the quotidian nature of white rage, the hegemony of whiteness persists in deflecting attention away from it. It is asserted that Canada is unlike the United States. Lynching, Jim Crow, mass incarceration, brutal and murderous police, racially biased immigration and a polemical racialized political culture is imagined to set us apart from the palpable and visceral white rage that is supposedly particular to the United 
States. The forced corralling of Indigenous Canadians onto reservations, African enslavement, Japanese internment and government sanctioned theft of their property, the Komagata Maru incident to exclude South Asians, the Chinese Exclusion Act, the refusal of Ashkenazi Jews fleeing death camps, segregation and so much more tell a different story

This Special Issue, which arose from our session at the 2019 Congress of the Humanities and Social Sciences_- "Whiteness in the Age of White Rage" — names and interrogates what is implicit in anti-racist, Indigenous and whiteness studies - white rage. Drawing on Carol Anderson (2017), we suggest a vital dimension of this configuration is a normalization of rage as a property right of whiteness. At this historical moment there is an opportunity for critical scholarship on whiteness in Canada to name and explicate to the social effects of rage. As our contribution to the Special Issue, we offer a general outline to this theme with an emphasis on epistemology, as well as an introduction to the works of the contributors: Dallas Jokic, Delia Douglas, Laura Mudde, and Shelina Kassam, as well as a book review of Jonathan Metzl's Dying of Whiteness: How the politics of Racial Resentment is Killing America's Heartland (2019) by Sarah Smith.

\section{Defining White Rage}

What, in cultural, social, and political terms, is meant by "white rage"? Carol Anderson (2017) writes that,

White rage is not about visible violence, but rather it works its way through the courts, the legislatures, and a range of government bureaucracies. It wreaks havoc subtly, almost imperceptibly. Too imperceptibly, certainly, for a nation consistently drawn to the spectacular - to what it can see. It's not the Klan. White rage doesn't have to wear sheets, burn crosses, or take to the streets. Working the halls of power, it can achieve it ends far more effectively, for more destructively. (Anderson, 2017, p. 3)

Anderson's conceptualization of "white rage" is intended to make visible its insidious machinations and, as she states, "to blow graphite onto that hidden fingerprint and trace its historic movements over the past 150 years" (2017, p. 3). While Anderson's conceptualization of white rage is intended to capture the American context of virulent antiBlackness, our goal for this Special Issue is that it be a part of this tracing in the Canadian historical and contemporary context of racism and whiteness. Our tracing does not dispute the subtle, "almost" imperceptible aspects of white rage, for they are pivotal in understanding the virulent aspects and outcomes of racial oppression. Our tracing, however, seeks to sketch an 
outline of the latent and manifest dimensions of white rage. In this context, then, we situate white rage as always in a dynamic process of cloaking (subtle, imperceptible) and uncloaking (visibly/manifestly violent) in relation to whiteness and racism in North America. We suggest the culture and politics of rage, as a property of whiteness, demands much more explicit theorization than it has received in Canada.

\section{Whiteness and Racial Domination: A Brief History}

Whiteness, as the manifestation of the complex interplay of imperialism, colonialism, capitalism, and European ("white") cultural practices - including religion and law — shaped being "white." Whiteness became a special property interest unique to European people —an invented "white" race made up of various ethnic groups perceived to have a common ancestry in various parts of Europe (see, for example, Allen, 1994; Du Bois, 1935; Harris, 1993; Jacobson, 1998). Whiteness became a franchise that, over 200 years, selectively and strategically incorporated a variety of Eastern and Southern European people once imagined as "not quite white" and among the "degenerate races." Over time the inter-ethnic conflation and fabricated racial appellation of "white" became a legal category for determining the rights and privileges bestowed on Europeans. Both in Canada and the United States, whiteness determined who could own property and who would be property, who could vote, who could own a business, who could ride on a bus, who could marry whom and who would live or die. Sanctified as a property right by custom and law, the colonialist-racial-state authorized the mass accumulation of wealth, power, and psychological advantage for white people (Brodkin, 1998; Ignatiev, 1995; Roediger, 1991).

From the early 17 th century to the 19 th century, slave-owning of both Indigenous and Black people was a widespread, although an uneven, practice in colonial Canada until its abolishment in 1834. Importantly, this white franchise necessitated the conferring of blackness onto the bodies of African-descended people to establish blackness as a condition of white property ownership ${ }^{1}$ (i.e., chattel slavery). As Barrington Walker (2010) notes, slavery "was a system of racially based economic coercion that was legally codified...[in] Canada... where the law...[of property ownership] was integral to producing blackness" (p. 5). Along with the black and white Manichaeism, the imputation of savagery onto the bodies of Indigenous

\footnotetext{
1 This is a simplified accounting of slavery and property ownership. Indigenous peoples in pre-Confederation Canada, such as the family of Joseph Brant, and in the United States, such as the Five Civilized Tribes, enslaved Black people in the southern United States. History also records instances where Black peoples were, for a brief period, slave-holders.
} 
peoples was necessary for the justification of Indigenous enslavement (in Lower Canada/New France) and colonial displacement. Bonita Lawrence (2016) points out, for example, that in the colony of New France two-thirds of the slaves were Indigenous until 1750, when the number of Indigenous peoples enslaved in French Canada began to decline. By 1834, with the abolishment of slavery in the British colonies, slaves of African descent far outnumbered Indigenous slaves. Subsequent anti-immigration policies and cultural investment in a "White Canada Forever" (Ward, 1990) ensured the creation and consolidation of a white cultural geography lubricated by white rage in a dynamic and dialectical process of cloaking (subtle, imperceptible) and uncloaking (visibly/manifestly violent). As such, within a colonial and white supremacist schematic of power, bodies and space are marked with meanings imposed by the state and the white settler colonial caste (Austin, 2013, McKittrick, 2006: Razack; 2002; Walker, 2010). Veritably, the belonging of Thobani's (2007) “exalted" subjects justifies the venting of rage at the ontology and perceived transgressions of the Other.

Latent and manifest articulations across Canada depended on regional and local proclivities. Sometimes white Canadians used indirect, somewhat cloaked means of ensuring the perpetuation of "white" privilege. For example, in 1912 legislators enacted a law ("White Women's Labour Law") preventing Asian men from hiring white women to work in their establishments. According to Constance Backhouse (1999), this law constitutes a remarkable point in Canadian history. It appears to be the first explicit racial recognition of whiteness in Canadian Law. Prior to this case, whiteness was inferred, but rarely stated in law-she calls this a mythology of "racelessness." This legislation was an attempt to prevent marriages between white women and Asian men. In contrast, measures taken against marriages between Black men and white women were far more direct - these unions often evoked an uncloaking of white rage. In one case, 75 members of the "Kanadian Knights of the KKK" (who were businessmen in Hamilton, Ontario) marched through the town of Oakville on February 28, 1930 in order to prevent an interracial marriage between a white woman and a man whom they believed to be Black. As the man was forcibly removed from his home, a large cross was nailed on his front lawn and set on fire. In another case, this one recounted by Susanna Moodie in her memoir, Roughing It In The Bush (1852), a group of white men dragged a newlywed Black man along railway tracks until he died.

These examples of legislation (cloaked) and manifest violence (uncloaked) are but a few examples of how white rage was enacted to protect and perpetuate the building of a "white" Canadian nation-state. Enakshi Dua (1999) reminds us that "through a discourse of race, the nuclear family emerged as one of the main institutions for constructing a racialized and gendered nation-state" (p. 248; see also Silvera, 1993). For example, domestic worker and 
seasonal agricultural schemes exploited the labour of Caribbean and Asian men and women while preventing the constitution of their families in Canada (see, for example, Silvera, 1993). For Indigenous peoples, the express aim of the State's "civilizing mission" has been cultural genocide of the family through the Indian Act and Residential Schools (Emberley, 2001; Fournier \& Crey, 2011). Fundamental to the settler nation-building endeavour was a legal apparatus of expulsions, constraints, and restrictions that perpetuated racial inequality and the aggrandizement of white power (Backhouse, 1999).

In the context of a society founded on white imperial and colonial violence, and justified through tropes of the dangerous Other, whiteness and thus white rage is never signified outside a process of racial domination. While, as Anderson argues, "white rage" can achieve its ends effectively, and sometimes more destructively by working in the halls of power, it nonetheless has (and needs) its moments of rupture-its "uncloaking." Why does it need to uncloak into enactments of visible violence?

The Canadian nation-state stands on an edifice forged through violence and profound inequality justified through constructions of "barbarians at the gate" - the ungodly, savage, but noble "Indian"; the "black" threat; the "yellow" menace - threatening to break through the gates and wreak havoc among the greater civilizing "white" race. Such an edifice-forged in and defended through violence-demands a securitization of its "white" gates from the enemies within and outside its borders. This defending includes a terrorizing of the "barbarians" - the "Other" - to discipline them into compliance and consign them to their rightful place in the racial/social order. From a psychosocial perspective, the uncloaking functions as a cathartic release that dialectically sutures the class divide among white subjects through the unifying function of an enemy.

But people and nations cannot "uncloak" and rule by visible violence alone (or for extended periods of time); it becomes more advantageous to conceal and "cloak" overt expressions of white domination. Franz Fanon (1964/67), in Toward the African Revolution, tangentially speaks to our cloaking metaphor. He states that

[f]or a long time it looked as though racism had disappeared. This soul-soothing, unreal impression was simply the consequence of the evolution of forms of exploitation. Psychologists spoke of a prejudice having become unconscious. The truth is that the rigor of the system made the daily affirmation of superiority superfluous. (Fanon, $1964 / 67$, p. 37)

It is not that whiteness and white rage have become fully cloaked but rather the daily, aggressive marking of whiteness as a property of white privilege has become unnecessary. It 
has become unnecessary, as Fanon states, because the rigour of the culturally patterned thought has made the daily marking of whiteness superfluous. The idea that daily affirmations of racism will be unnecessary also reflects the material dynamic that more and more people, including more and more of the white and middle class, are also superfluous. This sense of superfluity, thought to be proper for Black people, immigrants, Indigenous peoples, people of "colour" and even poor whites, is now biting hard at the heels of the white middle class. The result, it has been noted, both in Europe and in North America, is a turn to the right that links "nation" with "whiteness" and culture as a site at which the reaction to capitalism channels white rage (see, for example, Seidel, 1986). The cropping up of a range of groups from middle class khaki-wearing tiki torch bearers, "militias," an oddment of ex-military, police, and wannabe Rambo gun-toting defenders of whiteness, along with a silent majority from whom their ranks are drawn, reflect a culture whose whiteness is, in part, defined by seething and misplaced resentment.

Yet paradoxically, in the midst of growing economic redundancy, whiteness remains at the centre. In as much as whiteness is articulated as "positional superiority" and a structural location of advantage, it is wholly dependent on racism for its continued reproduction. And considering that racism has become structurally embedded in society and absorbed by the state (think, for example, of the criminal justice system or immigration system), overt individual daily affirmation of white rage is oftentimes superfluous. Fanon states that "racism has not managed to harden. It has had to renew itself, to adapt itself, to change its appearance. It has had to undergo the fate of the cultural whole that informed it" (1964/67, p. 32). In line with Fanon's argument, what is perceived as a subtle, almost imperceptible white rage can be explained as a renewal or an adaptation of white domination. Joel Kovel (1971), in a similar line of reasoning, calls this adaptation "metaracism." He explains that

$[\mathrm{m}]$ etaracism is a distinct and very peculiar modern phenomenon. Racial degradation continues on a different plane, and through a different agency: those who participate in it are not racists - that is, they are not racially prejudiced - but metaracists, because they acquiesce in the larger cultural order which continues the work of racism. (Kovel, 1971, pp. 211-212)

While racism now operates on a different plane and the daily affirmation of superiority through aggression has become unnecessary, this does not mean overt violence never occurs. On the contrary; we now bear witness to the moments when racial domination reasserts itself in overt forms through spontaneous displays of individual and state aggression that are in line with the principles of whiteness. The videotaped killings/murders of Black men by a militarized police force (e.g., George Floyd, Eric Garner, and Philando Castille, among 
others), the travesty of the law's legitimation of killer white vigilantes (e.g., Colton Boushie by Gerald Stanley's and Trayvon Martin by George Zimmerman), the murders and "incidental" killings of Black and Indigenous women (often in their homes) (e.g., Sandra Bland, Regis Korchinski-Paquet, Chantel Moore, and Breonna Taylor, among others), and the previously and much-publicized beating of Rodney King are all fitting examples of the convergence of individual and state aggression in the expression of white domination. As Kovel (1971) states, "what had been invisible becomes visible when it threatens the order of things, and that order attempts to adapt to the threat so as to maintain its underlying assumptions about the world" (p. 38). Those underlying assumptions support a cultural complex of whiteness, and one of the more important aspects of that culture is the way that anger is cloaked as a defining aspect of whiteness.

\section{Hate and White Extremism: Rethinking Middle Class and Statist Discourses on White Rage}

Frantz Fanon asserts that "[t]here are...cultures with racism and cultures without racism" (1964/67, p. 32). But to the extent that culture and race in the context of colonialism are dialogic with material exploitation under capitalism, racial ideology is a necessary condition to manage tensions between members of the exploiting group. Cedric Robinson (2000) refers to this historic process as "racial capitalism." In such a configuration, racism is a refutation of class conflict and an elevation of the supposed fundamentalism of inter-racial conflict. White labour, both working and middle class, effectively abdicate class solidarity in the historic conflict between capital and labour. By a process of substitution, the result of a presumed trans-class consensus and solidarity within whiteness cultivates a psychologyespecially in times of crisis - that seeks to avenge the white self for its meagre position in the capitalist social order. Most explicitly, for an assortment of white fundamentalists on the right "culture," in an essentialist sense, is the site at which their last stand against the "loss of their country" is made. It is here that through racial ideology whiteness exists as a trans-ethnic unifier and an identity to be defended. It is through this defence against - rather than a commitment to - class politics that anger emerges as a prerogative of whiteness. Particularly for members of the dominant racial group exposed to the vagaries of the market, anger in such configurations is a fundamental value in private and public life (see Douglas in this Special Issue). 
At this moment in Canada, the United States, and all Western countries, white anger is seething, manifest, pervasive, and even murderous. It is taking two forms. The first garbed in conservative political ideology, and the second in so-called hate crimes. Both serve as an approximate metric for white rage, but we suggest that, in excluding the quotidian practices of the middle class within the sanctum of institutional settings and shielding white women through gendered tropes of caring, we miss crucial constituents who express white rage.

At the conservative and right-wing ends of the ideological spectrum, "hate crimes" and the Alt-Right/Alt-Lite are indices of white rage. Influenced by an array of right-wing ideologues such as Richard Spencer and Milo Yiannopolous, young, hip, educated, techsavvy, middle class - and mostly male - white Canadian university students have embraced these brands of white supremacy. Indeed, supported by the similar claims of Jordan Peterson, affirmative action, employment equity and Equity, Diversity, and Inclusion initiatives are singled out as the clarion call for "everyday white people" who feel hard-done-by concessions to historically excluded groups. In Canadian universities - the bastion of the middle classwhite rage articulates itself through coded resistance to affirmative action/employment equity and the commitment to "free speech" (Pang, 2020; see also Perry, 2011). There is, as a result, growing awareness, but some (Gracie, 2018; Murray, 2020) suggest little urgency at extreme radicalization among white Canadian youth (Daigle, 2020).

The physically violent side of white conservatism can be measured by the growth of groups committed to physical assault and in the increasing number of police-recorded hate crimes (Perry \& Scrivens, 2019). Statistics Canada's reporting of police-recorded hate crimes shows a sharp increase in hate crimes after 2001, significant increases between 2006 and 2009 with a decline in 2007, and a general decline with peaks and troughs between 2010 and 2016 below recorded numbers from 2009 (Armstrong, 2019; Dauvergne \& Brennan, 2011; Silver, Mihorean \& Taylor-Butts, 2004). Since 2016, however - the year following race and xenophobic baiting federal election in Canada and the year Donald Trump was elected in the United States - acts of ethno-racial, religious, and LGBTQ2S hate crimes increased by 33\% over the 2009 reports. The General Social Survey indicates that there is significant underreporting of hate crimes from targeted groups, and that a significant minority in these groups, particularly Black Canadians, express fears of anti-Black racist assaults (Silver et al., 2004). Of all ethno-racial groups, hate crimes against Black Canadians have consistently increased, even over the period of a decline in hate crimes between 2009 and 2016 (Allen, 2014; Armstrong, 2019; Dauvergne, 2010; Dauvergne \& Brennan, 2011).

Religioius communities, particularly Islamic communities, have borne the brunt of murderous rage. In 2017 Canada's attention was drawn to the massacre of six worshipers and 
the wounding of 19 others at the Islamic Cultural Centre in Quebec City. In Toronto on September 12, 2020, Mohamed-Aslim Zafis was killed in front of the IMO Mosque. The Open Letter to Prime Minister Justin Trudeau on the eve of Zafis' murder pointed out that "In 2015, according to counter-terrorism experts in Canada, we had 100 alt-right or white supremacist groups operating in Canada. Now, we have over 300." (National Council of Canadian Muslims, 2020). The Chinese National Canadian Council reports that since COVID-19 there has been a significant increase in anti-Asian hate crimes (2020). Police-recorded hate crime statistics demonstrate that, at least since 2006, there has been a marked annual increase in hate crimes and violent assaults against various marginalized communities (Allen, 2014; Armstrong, 2019; Dauvergne, 2010; Dauvergne \& Brennan, 2011).

Be it the "Alt-right/Alt-light" or physically violent white supremacists, these trends are well documented by Barbara Perry and Ryan Scrivens (2019). Yet in limiting analysis and theorizing of white supremacy to varying forms of white extremism, Perry and Scrivens implicitly direct attention away from the foundational and quotidian nature of white rage - and therefore white extremism - in Canada among the middle class, white women, and the state. By thinking within the conceptual limits of the state definition of reality (i.e., hate as a crime), it is impossible to think of the white settler colonial state as the chief practitioner and propagator of hatred and white rage. This, of course, does not disavow that economic crisis is a source of the increase in "hate" crimes, nor that it is motivating reactionary politics, as well as a growing embrace of participatory totalitarianism (see, for example, Dean \& Altmeyer, 2020).

\section{The Unlikely “Deplorables”: The White Middle Class and White Women}

Toward enlarging the conceptual frame for thinking about white rage, we call attention to two general areas we think worthy of inquiry. It is vital at the outset to abandon the historic prejudice of middle class researchers to foist onto poor and working class white people the opprobrium that they are a "basket of deplorables." At the same time, one must guard against the Romanticism of the Chicago School tradition that turns the researcher into a zookeeper who, in "appreciating" "their" subjects, shields them from critical reflection as much from spectators who might throw stones (see, for example, Gouldner, 1968). All of this has the salutary effect of concealing the middle class from examining its own investment in white rage, which in reality differs only in degree, milieu, and method for its expression. The white poor and working class vent their rage by turning to arch conservative plutocrats, voicing 
complaints about "losing their country," feeling like "strangers in their own land" and venting their rage at immigrants and anyone that is different from them (Gest, 2016; Hochschild, 2016; Isenberg, 2016; Metzel, 2019; Vance, 2016). Here, however, is the significance of Fanon's (1964/67) and Kovel's (1971) analysis concerning the strategic methodology for the state and private bureaucracies embedding racism within rules and organizational practice. White middle class rage is coded and concealed, both by the discourse of civility and organizational priorities in the reproduction of capitalist, colonialist, and racist relations of domination.

From this perspective, a different order of questions arises to take us beyond the white middle class framing of anger and rage and that of state-sanctified definitions of hate. Questions might run along the following lines: Why cannot the state itself be a hateful and vengeful enterprise? The wilful abrogation of Indigenous sovereignty, be it forcing through pipelines or refusing to uphold treaty hunting and fishing rights might suggest so. When the police murder civilians, strip-search civilians, engage in racial profiling and carding and when they set their dogs on Black people, does this not connote white rage and sadism? Evidence from the Ontario Human Rights Commission may suggest so (OHRC, 2020; Wortley, Laniyonu, \& Laming, 2020). Does not the scandal of continued and grossly disproportionate child apprehensions from Black Canadian and Indigenous families smack of organized hatred and rage? Scholarly inquiry, news reports, and legal clinic reports gesture in that direction (Maynard, 2017; National Collaboration for Child Welfare, 2017). What of teachers, guidance counsellors, principals, and superintendents who call Black parents by racial epithets and, through criminalization and expulsion, expedite the school-to-prison pipeline for Black students? Reports from advocacy groups and school boards indicate that within the protective cover of schools, where their authority is nearly absolute, the white middle class are effectively destroying the future of Black children, and particularly those in the Greater Toronto Area (GTA) (Chadha et al., 2020; Morgan, 2016). These and other questions present themselves if we are to demystify the reality of white rage in Canada.

But in addition to rethinking class, it is vital to rethink the role of white women as contributors to the reproduction of white rage. It is imperative to get past strategic deployments of emotion and postures of defence that would obstruct analysis (see, for example, Srivastava, 2005). Researchers suggest that "stereotypes about women, which reflect gender and heterosexist biases, [which] include the notion that women are nurturing, submissive helpmates to men" need to be rethought (Stemple, Flores, \& Meyer, 2017, p. 302). Critical feminist scholars demonstrate that contemporary and historical evidence shows 
white women are complicit with colonialism, nationalism, racism, totalitarianism, and white supremacy much beyond being anomalies to be sequestered (Bannerji, 1993; Dua, 1999).

In Dallas Jokic's essay in this Special Issue, the question of women's roles in racializing anger as a property right of whiteness brings us to some appreciation of how rightwing white women enact masculinity and mobilize whiteness as patriarchy. Jokic writes,

Sheila Gunn Reid, a writer for the far-right website "The Rebel" tweeted a video of the counter-protestors disassembling the blockade, writing, "The protesters just stand there shitting their pants, totally stunned, as the scent of pure testosterone and vigor wafts past their nostrils and overwhelms their soy-dullened senses. Ladies, we almost don't deserve Alberta men." (Jokic, 2020, p. 17)

Abandoning the stereotype that white supremacy is only expressed by women in the KKK and other assorted vigilante and violent white groups entails an epistemic and methodological shift. Dawn McIntosh (2018) powerfully demonstrates that white women play an imperative role in recentering whiteness. She states that "[i]f White women are culturally organized as nurturing, innocent, and pure, then they are never racist. White supremacy is secured through White feminine enactments of whiteness while simultaneously running covertly under the radar as never marked in these hostile ways" (2018, p. 109; see also Leonardo \& Boas, 2013). McIntosh further notes that white women, especially middle class women, long ago made their compromise with colonialism, slavery, and imperialism. And, like their men of all classes, generally endeavoured to get as much out of racial capitalism as they could. The theorizing of gender, as if this means women and only really white women, requires consistent and critical scrutiny, for like middle classness we are more than likely to miss the ubiquity of white rage.

\section{Overview of the Special Issue}

The four essays in this Special Issue each attend to different articulations of white rage. Dallas Jokic's "Cultivating the Soil of White Nationalism: Settler Violence and Whiteness as Territory," is a theme that was most clearly articulated in German National Socialism (i.e., Nazism) — "blood and soil." The chief distinction, however, is that white settler colonialism is mapped, paradoxically, onto the claim that Canada is a liberal democracy. Jokic argues that white settler claims and rationalizations for the dispossession of Indigenous peoples in Canada rest on the Lockean assertion of property rights that inhere in both the state and the embodiedness of a rational white colonial settler. The key to Jokic's argument is that the white 
settler colonial state, through its conceptions of law and other methods of ideological hegemony, deputize the white colonial settler as a supplementary coercive force. Mobilizing Cheryl Harris's concept of whiteness as a property right, Jokic argues that the embodiment of whiteness is vested with the authority of the extra-judicial right to exclude, constrain and to kill Indigenous peoples.

In "Un/Covering White Lies: Exposing racism in the era of racelessness," Delia Douglas examines a Canadian court case that involves the largest arson homicide in the history of Vancouver, British Columbia. Drawing on Mbembe's concept of "necropolitics," Douglas shows how anti-Black and anti-Brown racism were motivations that meshed with the presumed right of a white supremacist to extinguish persons - immigrants and refugees deemed superfluous to Canada. Douglas considers the crime and the legal proceedings as a case study to further our understanding of discourses of race, racism, and citizenship in Canada where the politics of life and death are strongly contingent on white personal judgment. Mobilizing discourse analysis, Douglas demonstrates that crime, the investigation, and the trial communicate symbolically and materially what bell hooks (1992) characterizes as the "terrorizing force of white supremacy." Despite all claims to juridical equality purported by law and multiculturalism, the violence of coloniality and racism are shown to be embedded in the social arrangements of present-day white settler society.

If indeed, the white colonial settler state is in collusion to maintain relations of domination and dispossession, what becomes of speaking, receiving, and acting on truth? Laura Mudde's "Framing the Truth and Reconciliation Commission Process in Canada: A Media Analysis of Settler-Colonial Rhetoric and Colonial Denial, 2003-2016" reveals that truth is itself a commodity for the maintenance of white settler hegemony. The Truth and Reconciliation Commission (TRC) of Canada helped to expose the trauma experienced by Indigenous peoples in Canada's residential schools (IRS), governed and run by government and by state-deputized church officials in the white civilizing mission. While in 2008 the Canadian government formally apologized for these residential schools, it also routinely denies and undermines that recognition in other narratives that aim to cloak land and resource and appropriation, dispossession and abrogation of treaties. Undertaking a discourse analysis of five Canadian media platforms during and subsequent to the TRC process, the paper unpacks the cognitive dissonance of an apology that is concurrent with the rhetoric and practices of settler colonial denial. Drawing on concepts such as the white possessive, white rage, and white fragility, findings from the analysis substantiate the hypothesis that the TRC worked to retrench the power of the Canadian (white, settler) state through "bad faith" bargaining. 
Can white racism be an equal opportunity employer? Does white anger have interlocutors who are not epidermally or culturally white? If so, what are the implications for the cloaking of white rage when racial Others, approved by the white middle class, legitimate angry white herrenvolk defences of liberalism (i.e., whiteness as property)? Shelina Kassam's "Rendering Whiteness Palatable: The Acceptable Muslim in an Era of White Rage" demonstrates that a critical and underdeveloped aspect of metaracism is the granting of honorary whiteness to "Acceptable Muslims." She based her thesis on two Canadian case studies: 1) Irshad Manji, a Canadian Muslim journalist and activist who has been an active commentator on a variety of issues including those related to Muslims; and 2) the CBC sitcom Little Mosque on the Prairie (2007-2012), the first "mainstream" Canadian television series to feature a caste of multiracial Muslim and white characters. The Acceptable Muslim is palatably represented as assimilable, "moderate," "modern," urbane, and secular. By contrast, the Acceptable Muslim is neither an unjustifiably angry, "medieval," extremist Arab/Muslim male nor a long-suffering oppressed Arab/Muslim female. Centrally implicated in white Canadian herrenvolk debates about multiculturalism, gender equality, citizenship, and secularism, Acceptable Muslims (re)confirm and sustain, while cloaking, the racial boundaries of the nation-state. In the process, the Acceptable Muslims become iconic voices of multiculturalism and reason, reanimating the whiteness at the heart of the Canadian nationstate.

The contributors point to the ways that white rage is cloaked in policies and quotidian practices, uncloaked in murderous acts of white rage, and sometimes upheld by racial Others. By expounding on the epistemological relevance of white rage as a deeply entrenched aspect of Canadian culture, we hope this Special Issue contributes to the existing body of critical inquiry that supports resistance to colonialism and white supremacy in Canada. In addition, the review in this Special Issue by Sarah Smith of Jonathan Metzl's (2019) Dying of Whiteness: How the Politics of Racial Resentment is Killing America's Heartland offers an intriguing reflection on the boomerang effect of white people's commitment to white rage.

\section{Acknowledgements}

We are thankful to Dr. Wesley Crichlow for encouraging us to create a special issue from our session at the 2019 CSA conference at the Congress of the Humanities and Social Sciences, University of British Columbia. We wish to thank JCRI for allowing us the space to contribute to the critical scholarship on race and racism in Canada. We extend a special thanks to Laura Pascoe who worked tirelessly on this Special Issue in spite of the challenges of the COVID-19 
pandemic. Thank you also to the reviewers who took the time to engage with the readings and offer their expertise.

\section{References}

Allen, M. (2014). Police-reported hate crime in Canada, 2012. (no. 85-002-X). Canadian Centre for Justice Statistics. Statistics Canada.

Allen, T. (1994). The invention of the white race. London, UK: Verso.

Allen, W. S. (2020). Learning to become white girls in a settler colonial context: Exploring the racial socialization of white Euro-Canadian women. Settler Colonial Studies, 10(3), 378-402.

Anderson, C. (2017). White rage: The unspoken truth of our racial divide. Bloomsbury: Bloomsbury Publishing.

Anderson, K. (2016). A recognition of being: Reconstructing Native womanhood (2 $2^{\text {nd }}$ ed.). Toronto, ON: Canadian Scholars' Press.

Armstrong, A. (2019). Police-reported hate crime in Canada, 2017. (no. 85-002-X). The Canadian Centre for Justice Statistics. Statistics Canada.

Austin, D. (2013). Fear of a black nation: Race, sex and security in sixties Montreal. Toronto, ON: Between the Lines.

Backhouse, C. (1996). The white women's labor laws: Anti-Chinese racism in early twentiethcentury Canada. Law and History Review, 14(2), 315-368.

Backhouse, C. (1999). Colour-coded: A legal history of racism in Canada. Toronto, ON: University of Toronto Press.

Baldwin, J. (1955/1984). Notes of a native son. Boston, MA: Beacon Press.

Bannerji, H. (2000). The dark side of the nation: Essays on multiculturalism, nationalism and gender. Toronto, ON: Canadian Scholars' Press.

Bannerji, H. (1993). Returning the gaze: essays on racism, feminism and politics. Toronto, ON: Sister Vision.

Brodkin, K. (1998). How Jews became white folks and what that says about race in America. New Brunswick, NJ: Rutgers University Press.

Butler, J. (1993). Gender trouble: Feminism and the subversion of identity. New York, NY: Routledge. 
Carty, L. (1999). The discourse of empire and social construction of gender. In E. Dua \& A. Robertson (Eds.), Scratching the surface: Canadian, anti-racist, feminist thought. Toronto, ON: Women's Press.

Chadha, E., Herbert, S, \& Richard, S. (2020). Review of the Peel district school board. Peel District School Board. Retrieved from Ontario Ministry of Education website: http://www.edu.gov.on.ca/eng/new/review-peel-district-school-board-report-en.pdf

Chinese National Canadian Council (2020). COVID-19 Anti-Asian racism in Canada: A national picture. Retrieved from CCNC-SJ website: https://ccncsj.ca/more-anti-asianracist-incidents-reported-per-capita-in-canada-than-us-according-to-first-national-report/

Coulthard, G. S. (2014). Red skin, white masks: Rejecting the colonial politics of recognition. Minneapolis, MN: University of Minnesota Press.

Daigle, T. (2020, Jun 19). Canadians among most active in online right-wing extremism, research finds. $C B C$ News. Retrieved from www.cbc.ca

Daschuk, J. (2013). Clearing the plains: Disease, politics of starvation, and the loss of aboriginal life. Regina, SK: University of Regina Press.

Dauvergne, M. (2010). Police-reported hate crime in Canada, 2008. (no. 85-002-X). Statistics Canada.

Dauvergne, M., \& Brennan, S. (2011). Police-reported hate crime in Canada, 2009. (no. 85002-X). Statistics Canada.

Dean, J. W., \& R. A. Altmeyer. (2020). Authoritarian nightmare: Trump and his followers. Brooklyn, NY: Mellville House.

Deliovsky, K. (2010). White femininity: Race, gender and power. Black Point, NS: Fernwood Publishing.

Du Bois, W. E. B. (1935). Black reconstruction: An essay toward a history of the part which Black folk played in the attempt to reconstruct democracy in America, 1860-1880. New York, NY: Harcourt, Brace and Company.

Dua, E. (1999). Beyond diversity: Exploring the ways in which the discourse of race has shaped the institution of the nuclear family beyond diversity. In E. Dua \& A. Robertson (Eds.), Scratching the surface: Canadian, anti-racist, feminist thought. Toronto, ON: Women's Press.

Emberley, J. V. (2001). The bourgeois family, Aboriginal women, and colonial governance in Canada: A study in feminist historical and cultural materialism. Signs, 27(1), 59-85.

Fanon, F. (1952/1977). Black skin, white masks. New York, NY: Grove Press.

Fanon, F. (1964/1967). Toward the African revolution: Political essays. New York, NY: Grove Press. 
Foster, C. (2019). They call me George: The untold story of Black train porters and the birth of modern Canada ( $1^{\text {st }}$ ed., revised.). Windsor, ON: Biblioasis.

Fournier, S \& Crey, E. (2011). "Killing the Indian in the child": Four centuries of church-run schools. In M. J. Cannon \& L. Sunseri (Eds.), Racism, colonialism, and Indigeneity in Canada. New York, NY: Oxford University Press.

Gest, J. (2016). The New minority: White working class politics in an age of immigration and inequality. New York, NY: Oxford University Press.

Goldstein, J. S. (2004). War and gender. In C. R. Ember \& M. Ember (Eds.), The encyclopedia of sex and gender: Men and women in the world's cultures (pp. 107116). New York, NY: Kluwer Academic/Plenum Publishers.

Gouldner, A. (1968). The Sociologist as partisan: Sociology and the welfare state. The American Sociologist, 3(2), 103-116.

Hedges, C. (2017, February 20). James Baldwin and the meaning of whiteness. Truthdig. Retrieved from www.truthdig.com

Henry, A. (2015). We especially welcome applications from visible minorities: Reflections on race, gender and life at three universities. Race, Ethnicity and Education, 36(2), 227242.

Hochschild, A. R. (2016). Strangers in their own land: Anger and mourning on the American Right. London; New York, NY: The New Press.

hooks, b. (1992). Representing whiteness in the black imagination. In L. Grossberg, C. Nelson, \& P. A. Treichler (Eds.), Cultural studies (pp. 338-346). New York, NY: Routledge.

Ignatiev, N. (1995). How the Irish became white. New York, NY: Routledge.

Isenberg, N. (2016). White trash: The 400-year untold history of class in America. New York, NY: Penguin.

Jacobson, M. F. (1998). Whiteness of a different color: European immigrants and the alchemy of race. Cambridge, MA: Harvard University Press

James, C. E. (2021). Colour matters: Essays on the experiences, education, and pursuits of Black youth. Toronto, ON: University of Toronto Press.

Kovel, Joel. (1971). White racism: A psycho-history. New York, NY: Pantheon Books.

Lawrence, B. (2002). Rewriting histories of the land: Colonization and Indigenous resistance in Eastern Canada. In S. Razack (Ed.), Race, space, and the law: Unmapping a white settler society. Toronto, ON: Between the Lines.

Lawrence, B. (2016). Enslavement of Indigenous people in Canada. Retrieved from https://thecanadianencyclopedia.ca/en/article/slavery-of-indigenous-people-in-canada 
Lawson, E. (2002). Images in black: Black women, media and the mythology of an orderly society. In N. Wane, K. Deliovsky \& E. Lawson (Eds.), Back to the drawing board African-Canadian feminisms. Toronto, ON: Sumach Press.

McIntosh, D. M. D. (2018). From white ladies to white trash mamas: (Re)locating the performances of white femininity. In D. M. D. McIntosh, D. Moon, \& T. Nakaya (Eds.), Interrogating the communicative power of whiteness (pp. 94-116). New York, NY: Routledge.

Metzl, J. M. (2019). Dying of whiteness: How the politics of racial resentment is killing America's heartland. New York, NY: Basic Books.

McKittrick, K. (2006). Demonic grounds: Black women and the cartographies of struggle. Minneapolis, MN: University of Minnesota Press.

Moodie, S. (1852). Roughing it in the bush; Or, life in Canada. London, UK: R. Bentley.

Morgan, A. N. (2016). The blackening margins of multiculturalism: The African Canadian experience of exclusion from the economic, social and cultural promise and prosperity of Canada. African Canadian Legal Clinic. Retrieved from http://tbinternet.ohchr.org/Treaties/CESCR/Shared\%20Documents/CAN/INT_CESCR _CSS_CAN_22907_E.pdf

Murray, J. (2020, Feb 21). Former skinhead says white supremacy is part of Canadian identity. APTN News. Retrieved from www.aptnnews.ca

National Council of Canadian Muslims (2020, October 5). Open Letter to the Prime Minister: Taking action on white supremacist groups. Retrieved from National Council of Canadian Muslims website: https://www.nccm.ca/open-letter-to-the-prime-ministertaking-action-on-white-supremacist-groups/

Nelson, C. (2018). "Servant, seraglio, savage or Sarah": Examining the visual representation of Black female subjects in Canadian art and visual culture. In N. Reid-Maroney, B. E. de B'béri, and W. T. Bernard (Eds.), Women in the "Promised Land": Essays in African Canadian History. Toronto, ON: Women's Press.

$\mathrm{Ng}$, R. (1993). Sexism, racism and Canadian nationalism. In H. Bannerji (Ed.), Returning the gaze: Essays on racism, feminism and politics. Toronto, ON: Sister Vision.

Ontario Human Rights Commission. (2020). A Disparate Impact: Second interim report on the inquiry into racial profiling and racial discrimination of Black persons by the Toronto Police Service. Retrieved from Ontario Human Rights Commission website: http://www.ohrc.on.ca/en/disparate-impact-second-interim-report-inquiry-racialprofiling-and-racial-discrimination-black 
Pang, W. (2017). How the Alt-Right is winning over university campuses. The Walrus. Retrieved from https://thewalrus.ca/

Perry, B. (2011). Identity and hate crime on Canadian campuses. Race and Justice, 1(4), 321340.

Perry, B., \& Scrivens, R. (2019). Right-wing extremism in Canada. Switzerland: Palgrave Macmillan.

Razack, S. (2002). When place becomes race. In S. Razack (Ed.), Race, space, and the law: Unmapping a white settler society. Toronto, ON: Between the Lines.

Robinson, C. (2000). Black Marxism: The making of a Black radical tradition. Chapel Hill, NC: UNC Press.

Roediger, D. R. (1991). The wages of whiteness: Race and the making of the American working class. London; New York: Verso.

Silver, W., Mihorean, K., \& Taylor-Butts, A. (2004). Hate crime in Canada. Statistics Canada - Catalogue no. 85-002-XPE, 24(4), 1- 19.

Silvera, (1993). Speaking of women's lives and imperialist economics: Two introductions from silenced. In H. Bannerji (Ed.), Returning the gaze: Essays on racism, feminism and politics. Toronto, ON: Sister Vision.

Srivastava, S. (2005). "You're calling me a racist?" The moral and emotional regulation of antiracism and feminism. Signs, 31(1), 29-62.

Stemple, L., Flores, A, \& Meyer, I. H. (2017). Sexual victimization perpetrated by women: Federal data reveal surprising prevalence. Aggression and Violent Behavior, 34, 302311.

Thobani, S. (2007). Exalted subjects: Studies in the making of race and nation in Canada. Toronto, ON: University of Toronto Press.

Tuck, E., \& K.W. Yang. (2012). Decolonization is not a metaphor. Decolonization: Indigeneity, Education \& Society 1(1), 1-40.

Vance, J. D. (2016). Hillbilly elegy: A memoir of a family and culture in crisis. New York, NY: Harper/Collins.

Walcott, R. (2003). Black like who?: Writing Black Canada. London, UK: Insomniac Press.

Walker, B. (2010). Race on trial: Black defendants in Ontario's criminal courts, 1858-1958. Toronto, ON: University of Toronto Press.

Ward, W. (1990). White Canada forever: Popular attitudes and public policy toward Orientals in British Columbia. Montreal, QC: McGill-Queen’s University Press. 
Whitfield, H. A. (2019). White archives, black fragments: Problems and possibilities in telling the lives of enslaved Black people in the Maritimes. The Canadian Historical Review 101(3), 323-345.

Wortley, S., Laniyonu, A., \& Laming, E. (2020). Use of force by the Toronto police service: Final report. Ontario Human Rights Commission. Retrieved from Ontario Human Rights Commission website:

http://www.ohrc.on.ca/sites/default/files/Use\%20of\%20force\%20by\%20the\%20Toront o\%20Police\%20Service\%20Final\%20report.pdf 